\title{
Correlative Analysis of Data and Functions of Neuronal Synapse
}

\author{
T. R. Gopalakrishnan Nair ${ }^{1}$, A. Baby Jerald ${ }^{2 *}$ \\ ${ }^{1}$ Vice President-RIIC, Dayananda Sagar Institutions, ARAMCO Endowed Chair-Technology, PMU, Alkhobar, KSA \\ ${ }^{2}$ Research Associate-RIIC, Neuroscience Research Group Dayananda Sagar Institutions, \\ ARAMCO Endowed Chair-Technology, PMU, Alkhobar, KSA \\ Email: trgnair@gmail.com, 'babyjerald@gmail.com
}

Received February 15, 2013; revised April 1, 2013; accepted May 9, 2013

Copyright (C 2013 T. R. Gopalakrishnan Nair, A. Baby Jerald. This is an open access article distributed under the Creative Commons Attribution License, which permits unrestricted use, distribution, and reproduction in any medium, provided the original work is properly cited.

\begin{abstract}
Until recently, the synaptic transmission and excitatory amino acid transporters activation of neurons are very well discussed in the previous studies and are considered to be the two distinct features of Synapse. It is also found that a large number of interactions take place in the domain of ionic exchanges and protein interactions in synapses. It is evolutionary to have destined to release of Neurotransmitters to conduct an impulse to the other consecutive neurons, which forms the most important characteristic of synapse. From the popular perspective, it has been identified that detailed theoretical closer correlation of data produced through various studies about synapse can unravel many mysteries related to functions of synapse. Hence, this research paper tries to concentrate on a selected group of prominent characteristics and properties of synapse and also highlights some noteworthy discoveries, emphasizing the influential capabilities of them in the thought process and improving the knowledge of the field. It also highlights the expressive properties and forms of synapse brought out through the evidences available in sparse to dense data in a correlational way.
\end{abstract}

Keywords: Synapse; Synapse Formation; Synapse Gap; Synaptic Transmission; Synaptic Plasticity; Synapse Proteins; Functions

\section{Introduction}

It is commonly known that the mossy fiber system (MFBs) is a complex structure morphologically [1] and all the polarized nerve cells communicate via synapse, thus forms the developmental, functional, structural and trophic units of the nervous system [2]. Many known and unknown interactions occur within the central nervous system through synaptic contacts and transports. The study of synapse morphology and characteristics has recently taken under the domain of systems biology and computational biology as it has got the highest increased research interest. In this paper, the following subsections cover the knowledge on morphology and functions, along with certain other features like signal transmission and synaptic proteins. It has been a long term goal for many researchers to investigate neural and brain architecture and function to find appropriate reasons for many mental disorders, as there is a lack of deep information regarding the above mentioned topics. Hence, the pur-

"Corresponding author. pose of the paper is to provide a crisp and combined information of neuron synapse which is being pulled out from the available resources till today. This even handy information will help to indicate other properties such as synapse connectivity, synapse formation, synapse gap, transmission of signals via synapse and the role of some proteins in the synapse region and various disfunctions. Nevertheless even with these information, several other studies are required to take advantage of more diversified information on neuron synapse.

\section{Introduction on Synapse}

The synapse is a multi point interface that allows the electrical and chemical signal to pass from one neuron cell to the next cell. The synapse plays a key role in information processing in the nervous system that underlies many neurobiological processes including neurotransmission, learning and memory [3]. It has got the good machinery of linking two membranes together and passing signals between the cells and also there are distinct parts which 
emerge out to show that there are lots more strategies involved in the functioning of synapse. The formation of memories and the acquisition of new behaviors are thought to occur through the activity dependant regulation of synaptic connections in the brain [4]. Moreover while considering synapse as a unit, the first thing that strikes is the presence of the two major regions that are distinctively present with presynaptic and postsynaptic properties. It also involves the characteristic nature of synapse's ability to pass both chemical and electrical signal. The mechanism of the protein interaction and the release of neurotransmitter are considered as a fable and the information related studies are vast and diverse.

\section{Relative Findings}

Memory is one of the critical interest factors as far as brain properties are concerned. It can be dealt with starting from the superstars of clustered regions like Hippocampus, to the threads of single neuron and finally the proteins and its folding with ionization characteristics. Through the earlier studies and findings, enormous information has been brought out about the synapse origin and its functions including the perspective aspects of the formation of memory and the activity dependant regulation of synapse connections. However, certain readings say that the formation of memories and the acquisition of new behaviors are thought to occur through the activity dependant regulation of synaptic connections in the brain [4]. It is also found that the nearest neighbor distance favors the crosstalk of synapse and observed the distance between the presynapse and postsynapse in adults as 0.48 $\mu \mathrm{m}$ in MFBs [1]. In hippocampus MFBs, the plasticity of synapse is controlled by Munc 13 - 2 and hence it plays an important role in normal release probabilities [5]. The substantial evidence shows that the long term synaptic plasticity depends on the synthesis of proteins and also the inherent maintenance and modification of synapse enables long long-term memory [6]. As proteins play markable role in neurons, the unfolding of proteins can cause some disorders and may lead to certain mental disorders. The study of FMR1 (Fragile X Mental retardation 1) prone protein indicates that it accelerates the formation of proteins in the synapse and its low carbon content leads to disorder and therefore results in mental disorder [7].

In the recent past, the author [8] proposed that the presynaptic muting is induced by calcium independant inhibitory G-protein signaling. On the basis of neural circuits, the observation of adaptive presynaptic silencing indicates that it functions over a range of physiological conditions [9]. Similarly the author [10] noted some evidence on presynaptic silencing based on cAMP signaling. These findings hint at the possibility that prolonged cAMP signaling create presynaptic silencing. Though, the study reveals the cause for presynaptic silencing, does the exis- tence of presynaptic silencing induce any functional mechanisms? But it is clear that there is inadequate information on induction and expression mechanisms of presynaptic silencing [11-13]. Furthermore, intense theoretical and in vitro studies can unravel the difficulties in understanding the neural circuits. For this reason some of the qualitative researches have been analyzed to provide a novel outlook in a fair and evenhanded way.

\section{Synapse Formation}

The neuron doctrine started in the 19th century and later hit many new discoveries along with the introduction of neuronal networks. It led to neuron mapping, whereas the previous findings provided the platform to identify the molecular changes in the brain and bring up the revolutions in the corresponding field. It was Santiago Ramon Y. Cajal (1852-1934) [14] who suggested that the neuron was the anatomical and functional unit of the nervous system, and it is largely because of his work that the Neuron Doctrine eventually got accepted. Cajal was an outstanding neuroanatomist who is regarded as the father of modern neuroscience. He made many contributions to our understanding of the organization of the nervous system. The structural information and the parts of neuron are well known now but still there are several questions like how the transformation of signals from one cell to another cell take place and the communication between them get established. There are evidences of the fact that the postsynaptic density contains high concentrations of cell adhesion molecules, neurotransmitter receptors, ion channels, and signal transduction proteins and the occurrence of the synaptic gap [15-17]. For now, there were no clear closures on synaptic gap and also on the communication of nerve cells. Arguments still continue on the same topic but as of now we know that there is a gap between the nerve cells and that contains the secrets of information transduction, which was apparently stressed by Cajal and other scientists. Viewed as a whole the human nervous system is primarily concerned with the processing of sensory input or with the execution of motor output which is a physical action.

The formation of synapse is found to be accompanied with the modifications of actin cytoskeleton. The author [18] in his reference says that the polymerization and organization of actin into complex superstructures, includeing those found in dendritic spines are indispensable for the structure and function of neuronal networks. Furthermore it is clear that the morphological changes depend on the kinetics of major structural component of the postsynapse which is actin cytoskeleton [19-21]. The modification of proteins has become a vast subject which is accompanied by many unknown interactions. So far the invention has supplied us with basic resources to find unknown mechanisms. 
The author [18] said that the over expression of the two Abp1 [Filamentous actin (F-actin) binding protein] F-actin-binding domains increases the length of thin, filopodia-like and mushroom-type spines but dramatically reduces mushroom spine density, attributable to lack of the Abp1 Src homology 3 (SH3) domain. In contrast, overexpression of full length Abp 1 increases mushroom spine and synapse density. In fact this has been analyzed after doing staining techniques and also with high microscopic and quantitative analyzes. He himself demonstrates experimentally that Abp1 mediated effects on spine head and synapse formation depend on ProSaps (proline rich-Synapse associated proteins). For the experiment, he used RNAi-mediated Knockdown of ProSAP2 [22]. On the whole when we think about the formation of synapse, it has been apparently known that Abp1 executes the spine head and synapse formation.

The Author [18] concludes with effective information. The protein modification is another complex topic in which unknown interaction occurs but it plays a major role in the formation and function of synapse. Though the experimental techniques are cost effective, the Author has justified his work with the valid results. Here, a hope of positive indication is derived and it helps to hold on a rope to further inventions that make evolutionary effect. At this instance it is important to hunt the truth behind synapse and to analyze what exactly is happening in synapse. In particular, there are several cellular and molecular processes control the formation, function and remodeling of chemical synapse (see review of [23])

Recent advancements show the formation of synapse enabled by lithium. It induced the formation of synapse via inositol depletion and subsequent down regulation of the phophoinositide signaling cascade in the hippocampus region [24]. In case of previous Research, it shows that Glial cells participate in the synapse formation and it can detect neuronal activity and transform synaptic function, as well as endorse synapse formation, repair, and stabilization [25-30].

\section{Synapse Connectivity}

Most of the recent studies focus on faster and more prevalent synaptic connections as the information is also sparse. The excitatory neurons on cerebral cortex when compared with MFBs are found to connect with the dendritic spines and the reason; more axo-dendritic connections were observed and named as potential synapses [31-33]. Determining which of the strategies signify the connectivity pattern is found to be difficult as more factors are irresolute. Generally excitatory connectivity depend upon the neuron morphology and the recent study tried to get the different connectivity patterns by converting potential synapses into actual within the stipulated area [34]. To the interest, the author [34] also says that the cells decide the synaptic connections with the neighboring synapse and the cells that are compatible synaptically will endeavor converting potential synapse into actual and facilitate multiple connections.

The second factor influences the synaptic connectivity is the ability to cooperate and the connection strength between the positively correlated neurons after spine maturation [35-38]. Indeed, it takes place when the synapse is electrically activated. Henceforth, the potential synapses abide some molecular activity and some activity dependant rules [35]. Thus, the synaptic connectivity appears to be induced by the external outgrowth which is again directed by the pre and postsynaptic activity of the neuron within the predetermined area of the brain $[39,40]$. Recalling the earlier discussion, the Intercortical and intracortical connections depend on synapse potentiation and specifically intracortical connections are found to have ten release sites. Subsequently the connection mechanism between different types of neurons and connection specific connections are still being indefinite [41].

Searching for biologically more relevant conformation on synaptic connectivity is still in progress and the very recent research compares the amplitudes of action potential dependant spontaneous synaptic currents with the amplitude of the synaptic currents that are free of action potentials to analyze the average connectivity of potential synapse against a postsynaptic neuron [42]. It is also been derived that GABAergic interneurons and the pyramidal cells shows equivalent development of GABAergic connectivity but differs with glutamatergic connectivity in the recent research by the author [42]. This portion of research seemingly poses great challenge for the researchers and has surprisingly large effect on neuron investigations based on mental complications.

\section{Short History on Synapse Gap}

Synapse gap is still remaining as an unconvinced subject and there are arguments about synapse gap till today among the scientists. With reference to the available resources, it has been already proven that there is a synaptic gap [43] and it is summarized in the earlier discoveries by the author [44] about the synaptic structure and the neuron doctrine. In his reference he said the author [45] did research on axon and its branches where it connected to one or more synaptic terminals and also might have observed the synaptic gap as the second system of axon. However it also made us to think on this particular aspect and it is agreeable that [45] might have thought the continuation of axon; he wouldn't have noticed the discontinuity there which called as synaptic gap. It is clearly understood that it has been a tough task to come to a conclusion under light microscopic studies which evoke in some misunderstandings between scientists. It is very clear to predict this apparently as we understand the 
mossy fiber system and the complexity in predicting the structure of synapse gap. Before we conclude with any previous inventions, we should walk a mile in their shoes to get a catch with the history.

The Author [46] is the one to describe the synaptic gap as the second system of axon and it is also been observed that this issue is one of the most captivating for decades $[44,47]$. It is illustrated that $[45,46]$ tried to work on all components of the cell to show the neural processing and the author's [48] work focused on partial staining of the nerve cell which was not done formerly and he could observe the discontinuity of free ending axons. To the surprise, these free terminating axons indicates the presence of synaptic gap using silver staining methods but he didn't speak about synapse gap instead he said the axons fuses to form a reticulum. The author [48] is one of the very old leading scientists to throw a vision on neuron doctrine and in particular in view of the renewed international interest with exciting research methodologies. Later Cajal (1954) [14] proposed a neuron theory based on Golgi methods and he is the one to describe on synaptic gap between the axon terminal and the dendrites. The author [49] found the intercellular grey matter which has integrated with many cellular functions [50]. The current research shows the adhesion of various molecules in the presynapse and the postsynapse which are likely to be involved in synapse formation. The NGL-3 (Netrin G Ligand-3) that found in the postsynapse adheres with the presynaptic LAR (leukocyte antigen related) family proteins and thus regulates the formation of synapse bidirectionally [51].

By promoting electrical and biochemical coupling between the neurons, the synaptic junction accelerates the development of neural circuits and favors potentiation of synapse [52-56].

\section{Synapse Stability}

Once the signal passes, the transmission occurs via synapse to reach the other cell. The receptors are the recognition site in the post synapse and these are among the first molecules to accumulate at sites of nascent synapses [57]. This process is similar to molecular docking but here the neurotransmitters are the one to bind to the receptors. It is believed that many forms of activity dependant regulation of synapses, established in vitro and in vivo require activation of NMDA-type glutamate receptors (NMDARs) [58-60]. These receptors play a main role in LTD (Long Term Depression) and LTP (Long Term Potentiation). It is found that in immature synapses the induction of NMDARs-dependant results in long term potentiation $[61,62]$ and in mature synapses it is seen as the removal of AMPARs after the induction of NMDARdependant long term depression [63,64]. Henceforth it has been very clear that NMDAR, by regulating LTD and
LTP induction, control the maturation and stabilization of synapses over longer time scales [65]. There is voluminous information given by the Author and a peer group of more than hundred eminent scientists are working on synapse functions. Figure 1 gives the general view of synapse and its components and the release of neurotransmitters from the vesicle diffuses through the cell membrane which is attached to the receptors in signal propagation.

\section{Transmission of Signals}

Sudden changes in the ionic concentrations induce ion channels to intake sodium ions. This brings the change in the ionic gradients around the cell membrane and the impulsion transferred downwards from the dendrites to synapses and these impulses are referred as signals. The previous studies [66] shows that the presynaptic nerve terminals and the postsynaptic target cells signals to each other as they establish precisely aligned synaptic specializations. It's a question how this signal transmission occurs within a network of neurons and how does it reaches the target neuron. It can be answered on predicting the behavior of these signals when they propagate through complex neuron network. Earlier studies reveal that there are some specific signaling pathways through which Signals has been transferred and it is been distinguished after the introduction of the signaling through the second messengers and the intracellular pathways. It has taken more than three decades to find the measurements of changes in cytosolic cAMP and free $\mathrm{Ca}^{2+}$ concentrations [67].

Cellular signaling is a huge complex network and the signaling pathways carry and process information between the networks and exhibit bodily actions. There can be many inputs of information such as summation and

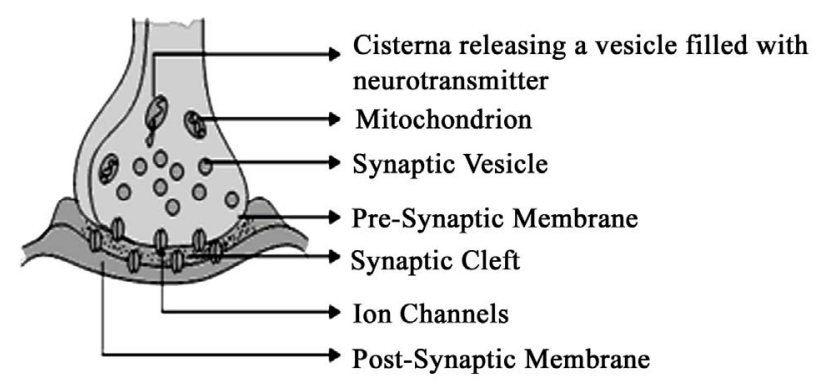

Figure 1. A schematic sketch of synapse showing the components and the vesicles that release neurotransmitters. In this image, it is shown that the presynaptic neuron releases the neurotransmitters after the breakdown of vesicles and therefore binds to the postsynaptic receptors that embed in plasma membrane. The signal transduction again depends upon the receptor activation and it can be either electrical or a secondary messenger pathway. The chain reaction of excitation or inhibition is found taking place at the receptor site. 
temporal integration during the propagation of signals. It is apparent that the release of neurotransmitters in to the cleft propagates the signal transmission. The reuptake of neurotransmitter, in this case its glutamate in MFBs is carried out with the help of glutamate transporters [68, 69]). The signal transmission follows specific pathways to reach the target. Recently the development of computational simulations can resolve the complexity in understanding the signal propagation as they consider all motifs as nodes and there have been emerged many simulation tools to analyze signal propagation. Generally Mossy Fiber synapses considered as strong synapses. It is observed in generating high postsynaptic currents and potentials in CA3 pyramidal neurons and interneurons $[70,71]$. Synaptic transmission is observed to depend mainly on the active zones, where the release of transmitters takes place and it is observed mainly within the puncta adherentia, putative adhesion complexes. It is also understood that the distance between the active zones provoke the fast transmission of signals and the efficacy of the synapses is directly proportional to the synaptic vesicles. In adult it is approximately 900 vesicles located within the $60 \mathrm{~nm}$ from the active zone which was observed from the quantitative analyzes by the author [1]. It is clearly represented in Figure 2, it shows the mean number of synaptic vesicles within the active zone. For more information related to efficacy of synapse (see review of [72]).

Amongst the various reasons, the major cause for signal transmission is the release of neurotransmitters. It mainly depends on the flow of $\mathrm{ca}^{2+}$ ions in to the presynaptic region through $\mathrm{ca}^{2+}$ ion channels. The distance between the $\mathrm{ca}^{2+}$ channels and the sensor triggers the breakdown of vesicles, ultimately transfer the signals. Other important factors like buffering kinetics of $\mathrm{ca}^{2+}$ and the number of docked and primed vesicles are also plays an important role in the release of neurotransmitters [73].

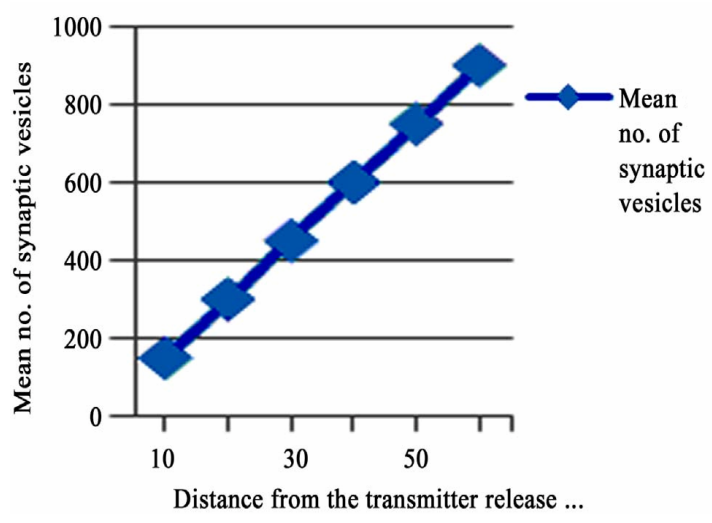

Figure 2. The correlation of synaptic vesicles within the active zone (Transmitter release site) in adults. Resketched from the data obtained by the author [1].
There are cases where the retrograde signaling takes place in synapses [74].

\section{Synapse Proteins}

The multiple functions of the synapse depend on molecular interaction that guided through synaptic proteins. The analysis of multivariate proteins involved in synaptic connections is an ongoing endeavor in proteomics. The protein database facilitates the collection of information about synaptic proteins. It is comprised of protein structure, function, interaction, pathways and expression (SynDB, http://syndb.cbi.pku.edu.cn) [75]. There exist some uncovered proteins which were detected after the year 2006 till today. Probably that might have attained much importance in recent research in neuroscience. The protein modulations and the derived functions of different synapses are listed in the table (Table 1). Almost all protein interactions results in specific function like the interaction of dentate gyrus and CA3 morphologically different regions influences the information processing in hippocampas region which involve series of protein interactions [7678].

On the other hand degradation of proteins acts as a modulator of synaptic physiology [79-81]. The degradation process streams down through selective pathway named Ubiquitin Proteasome System (UPS). The UPS controls the half life and the activity state of protein by linking the proteins with ubiquitin through enzytmatic activities [82]. Other than degradation of proteins, the UPS inhibition found to raise the release of neurotransmitters in mammals. In fact it is proved that it takes part in the regulation of synaptic transmission [83].

\section{Improved Outlook on Synapse}

Determining the biologically more relevant conformation about synapse function is still difficult for two main factors that are electrical and chemical transmission. It is believed to be controlled by membrane potential [102]. One of the most answerable questions is, whether the electrical transmission takes place in the absence of chemical transmission or both electrical and chemical transmission occurs simultaneously. For this query, the more comprehending salvation is proposed by the author [103]. In his study, he reveals that electrical synapses arise before chemical synaptogenesis. Henceforth, it cannot be assumed that the transmission patterns will be sufficiently similar to extrapolate from one neuron to another as it is controlled by membrane potential [104]. On the whole the underlying mechanisms for synaptic transmission is quiet out of the ordinary facts, in particular the controlling mechanism of interneuron synaptic plasticity which is based on induction and polarity [105]. Another rare findings appeal that the short term and long term plasticity are 
Table 1. Proteins found in different synapses and their functions.

\begin{tabular}{|c|c|c|c|c|}
\hline S. no & Protein name & Location & Description & Author \\
\hline 1. & $\begin{array}{l}\text { Calcium/Calmodulin } \\
\text { activated phosphatase } \\
\text { calcineurin }\end{array}$ & Neuronal synapses & Dephosphorylate endocytic proteins & Tao Sun et al., 2010 [84] \\
\hline 2. & $\begin{array}{l}\text { Calcium/Calmodulin } \\
\text { dependant Kinase II }\end{array}$ & $\begin{array}{l}\text { It's a component of electrical } \\
\text { synapse in the mauthner cell }\end{array}$ & $\begin{array}{l}\text { It is requires for the induction of changes } \\
\text { in both forms of transmission }\end{array}$ & $\begin{array}{l}\text { Carmen E Flores et al., } \\
\text { [85] }\end{array}$ \\
\hline 3. & Connexin (Cx35) & $\begin{array}{l}\text { Synaptic terminals on the teloest } \\
\text { mauthner cell }\end{array}$ & It undergoes activity dependant potentiation & $\begin{array}{l}\text { Carmen E Flores et al., } \\
\text { [85] }\end{array}$ \\
\hline 4. & $\begin{array}{l}\text { Adenomatous polyposis } \\
\text { Coli Protein (APC) }\end{array}$ & $\begin{array}{l}\text { It organizes a complex multiprotein } \\
\text { that directs nicotinic acetylcholine } \\
\text { receptor (nAChR) localization at } \\
\text { postsynaptic sites in avian ciliary } \\
\text { ganglion neurons in vivo }\end{array}$ & $\begin{array}{l}\text { It coordinates presynaptic and postsynaptic } \\
\text { maturation and promotes synaptic efficacy. } \\
\text { It also promotes retrograde signals via } \\
\text { postsynaptic neuroligin that interacts with } \\
\text { presynaptic neurexin extracellularly }\end{array}$ & $\begin{array}{l}\text { Madelaine M. Rosenberg } \\
\text { et al., [86] }\end{array}$ \\
\hline 5. & $\begin{array}{l}\text { Calcium/Calmodulin protein } \\
\text { kinase II } \alpha(\mathrm{CaMk} \text { II } \alpha)\end{array}$ & CA1 hippocampal neuron Synapse & $\begin{array}{l}\text { Central role in regulating neuronal } \\
\text { excitability and now it is observed to } \\
\text { directly phosphorylate the inhibitory } \mathrm{GABA}_{\mathrm{A}} \\
\text { receptor }\left(\mathrm{GABA}_{\mathrm{A}} \mathrm{R}\right) \alpha 1, \beta 2 \text { and } \gamma 2 \text { subunits }\end{array}$ & Marsdena et al., [87] \\
\hline 6. & $\begin{array}{l}\text { Postsynaptic Scaffolding } \\
\text { protein gephrin }\end{array}$ & $\begin{array}{l}\text { GABAergic synapses in the } \\
\text { hippocampal neurons }\end{array}$ & $\begin{array}{l}\text { It's a synaptogenic molecule regulating } \\
\text { GABAergic synaptic plasticity and } \\
\text { contributes the therapeutic action of lithium }\end{array}$ & $\begin{array}{l}\text { Shiva K. Tyagarajan et } \\
\text { al., [88] }\end{array}$ \\
\hline 7. & $\begin{array}{l}\text { Soluble guanylyl cyclase/ } \\
\text { Protein kinase G and rho } \\
\text { A/rho kinase }\end{array}$ & $\begin{array}{l}\text { Motoneurons at adult and neonatal } \\
\text { stages. }\end{array}$ & $\begin{array}{l}\text { Neurodegenerative process/Synapse } \\
\text { elimination }\end{array}$ & $\begin{array}{l}\text { Carmen R. Sunico et al., } \\
\text { [89] }\end{array}$ \\
\hline 8. & Protein kinase $\mathrm{C}$ & Aplysia Sensory Neurons & $\begin{array}{l}\text { Formation of specific synapses and } \\
\text { maturation of the synapse by activating } \\
\text { the additional signaling pathways }\end{array}$ & $\begin{array}{l}\text { Jiang-Yuan Hu et al., } \\
\text { [90] }\end{array}$ \\
\hline 9. & $\begin{array}{l}\text { Leucine rich repeat } \\
\text { transmembrane neuronal } \\
\text { proteins }\end{array}$ & Glutamatergic synapses & Promotes synaptic differentiation & $\begin{array}{l}\text { Tabrez J. Siddiqui et al., } \\
\text { [91] }\end{array}$ \\
\hline 10. & $\mathrm{BDNF} / \mathrm{TrKB}$ & CA1 hippocampal neuron & $\begin{array}{l}\text { Key mediators of axon guidance, } \\
\text { Synapse formation and Plasticity }\end{array}$ & $\begin{array}{l}\text { Huang and Reichardt } \\
\text { 2003; Luikart and Parada } \\
\text { 2006; Lu et al., } 2008 \\
\text { [92-94] }\end{array}$ \\
\hline 11. & Phocein proteins & Neuromuscular synapses & $\begin{array}{l}\text { Regulation of axonal transport, neurite } \\
\text { elongation, synapse formation, and } \\
\text { microtubule organization }\end{array}$ & $\begin{array}{l}\text { Joost Schulte et al., } 2010 . \\
\text { [95] }\end{array}$ \\
\hline 12. & $\begin{array}{l}\text { Synaptic adhesion like olecule } \\
\text { (SALM family proteins) }\end{array}$ & Neuronal synapses & Synapse formation & $\begin{array}{l}\text { Won Mah et al., } 2010 . \\
\text { [96]. }\end{array}$ \\
\hline 13. & Synapsin & Neuronal synapses & $\begin{array}{l}\text { MAPK/ERk dependant synapsin } \\
\text { phosphorylation initiates the functional } \\
\text { synaptic connections and their short term } \\
\text { plasticity }\end{array}$ & $\begin{array}{l}\text { Carlo Natale Giuseppe } \\
\text { Giachello et al., } 2010 \\
\text { [97] }\end{array}$ \\
\hline 14. & Docking protein 7 (Dok-7) & Neuromuscular synapses & $\begin{array}{l}\text { Involves in synapse formation by recruiting } \\
\text { adaptor proteins named Crk and Crk-L }\end{array}$ & $\begin{array}{l}\text { Peter T. Hallock et al., } \\
2010 \text { [98] }\end{array}$ \\
\hline 15. & Cysteine string protein $\alpha$ & Hippocampal synapse & Maintain presynaptic function & $\begin{array}{l}\text { Pablo } \\
\text { García-Junco-Clemente } \\
\text { et al., } 2010 \text { [99] }\end{array}$ \\
\hline 16. & $\begin{array}{l}\text { Cc2d1a-evolutionary } \\
\text { conserved protein }\end{array}$ & Central nervous system & $\begin{array}{l}\text { Controls functional maturation of } \\
\text { synapses in mouse }\end{array}$ & $\begin{array}{l}\text { Meng Zhao et al., } 2011 . \\
\text { [100] }\end{array}$ \\
\hline 17. & Cholecystokinin & $\begin{array}{l}\text { Mammalian brains including } \\
\text { hippocampus }\end{array}$ & $\begin{array}{l}\text { Facilitates presynaptic glutamate release } \\
\text { (glutamatergic transmission) }\end{array}$ & $\begin{array}{l}\text { Pan-Yue Deng et al., } \\
2010[101]\end{array}$ \\
\hline
\end{tabular}


target cell specific and also it emphasis that it rely on phenotypic properties of the interneuron especially in receiving the input signals from the neighboring cell [106, 107]. As controversy proceeds on synapse transmission, it is evident that astrocytes regulate synaptic transmission by interacting with neurons. In recent times, an extensive research tried to experiment the role of gap junction proteins connexin 30 and connexin 40 in synaptic physiology. They extend the work by blocking the activities of connexin 30 and connexin 40 genes, thus evolved that there is a delay in synaptic transmission in CA1 pyramidal neurons and affirmed that connexins than any other proteins play equally important role in synaptic plasticity. It also stressed that the role of astrocytes in chemical synapses which is truly based on the modulation of astroglial clearance rate and ultimately controls the neuron excitation, neurotransmitter release, postsynaptic receptors, potassium ion removal from the extracellular matrix and the silencing synapses [108]. As with other important factors that simulate the synapse potentiation, the ERK1/2 signaling plays a vital role in long term potentiation in hippocampal neurons [109].

Some factors do appear to elicit synaptic transmission. The high degree of receptor activation was found to be mediated by endocannabinoids especially in retrograde signaling system in the brain [110]. There also observed hyperactive interneurons associated with the increase of potassium ions from 2.5 to $10 \mathrm{mM}$ in the extracellular matrix [111]. Finally, the laboratory experiment demonstrates that the increase of potassium ions in the extracellular matrix activates GABA receptors in the postsynapse of CA3 pyramidal neurons [112].

\section{Common View on Synapse Today}

Other than classical synapses, some group of neurons communicates in an unusual way. It is observed that neurogliaform cells inhibit the transmission of signals to the neighboring cortical neuron with GABA neurotransmitters. In this case, it is a revelation as there are no synapses involved in this transmission and it is purely by chemical transmission [113]. Upcoming research targets neuronal polarity because of its role in brain disorders. As a result, involvement of gene in the synaptic defects has been identified. Therefore, in existing neurons, these genetic evidence studies reveal that the level of phosphoionositides (PIP2) control the neuronal polarity which inturn controlled by the enzyme myo-inositol monophosphatase (IMPase) and thus believed to promote polarized synaptic components [114]. In glutamatergic synapses, excitatory amino acid transporters (EAATs) regulate AMPA receptor (AMPAR) accumulation in the postsynapse and the synaptic efficacy depend on the AMPAR accumulation. If EAAT fail to function, glutamate disseminates in to the synaptic cleft and get bind to the
NMDA receptor (NMDAR) [115]. The mechanism by the EAAT affects the AMPAR localization in synapse is questionable. For this reason the resources are becoming fewer and the difficulty and the complexities in understanding the activation of AMPARs produce a delay in the report of data in the particular field.

\section{Discussion}

The Synapse and its function are intricately entangled with the neuron function and signal propagation. Researchers are yet to work for many years by being far apart in silos achieved less to form a hypothesis about the functions of brain and the model of neuron connections to realize the signal transmission between them. Now with technology advancements, it is easy to learn several phenomena within the broad restraint of neuroscience. This review correlates several well defined proteins and functions of synapse. It is not projecting the fact that synapse and related fields have been studied in an extraordinary way to recreate memory and learning. In fact, the potential of this work lies in identifying certain hitherto, explored evidences and project it for further evaluations and cross correlations for better perception of this field.

The science of neurons is still a new and developing area which calls for a special educational domain as Neuron Science rather than the conventional psychology embedded Neuroscience. It must deal with very fast fields like Electronics, Electrochemical, Chemical and Protein Dynamics for information encoding and decoding. The initiative behind this work focusing on the synapse formation and the signal transmission is to create certain perspectives. It gives a correlative presentation of properties to the certain extent based on the latest achievements in the field. Hence it is not covering certain earlier studies, but it positioned itself to cover recent expositions of synapse. It mainly highlights synapse formation with the actin binding protein as it increases the synaptic density, the long term potentiation and the long term depression which maintains the synaptic stability, the specialized pathways in neuronal network, and the receptor binding sites. The basic mechanism is mediating between the presynaptic and the postsynaptic region and gives well perceptive on synaptic functions. On the whole, the author [116] rationalizes his work by presenting a review on neuron doctrine which is an eminent effort to trespass the past history on neuroscience and perhaps helped this writing more meaningful.

\section{Conclusion}

The study attempts to present a more recent uniform assessment of synapse region which is predominantly the most valuable one in a neuron. Most of the Neuroscience studies and inventions really originated from the scree- 
ning of early studies. The synapse formation involves many protein interactions and the modification of actin cytoskeleton elements. The synapse density is found to rely much on the actin binding protein which can provide further knowledge on the formation of synapse. The lack of standardization in assay procedures particularly on synaptic properties is highlighted here as a priority concern. Testing the hypothesis with experimental techniques is fundamentally complicated. For that reason, this review paper confers on previous eminent works on neuron synapse. It is possible to reach much deeper understanding of neuronal capabilities and clustering with significant improvements by applying new technologies and incorporating challenging computer simulations.

\section{Acknowledgements}

This work was supported by the research and industry incubation centre, Dayananda Sagar Institutions. We thank Dr. Suma V. for her support in research methodology. We also thank Mrs Reena Phillips for her assistance in creating the synapse diagram.

\section{REFERENCES}

[1] A. Rollenhagen, K. Satzler, E. P. Rodriguez, P. Jonas, M. Frotscher and J. H. R. Lübke, "Structural Determinants of Transmission at Large Hippocampal Mossy Fiber Synapses,” The Journal of Neuroscience, Vol. 27, No. 39, 2007, pp. 10434-10444. doi:10.1523/JNEUROSCI.1946-07.2007

[2] R. W. Guillery, "Observations of Synaptic Structures: Origins of the Neuron Doctrine and Its Current Status," Philosophical Transactions on Royal Society Lond B Biological Science, Vol. 360, No. 1458, 2005, pp. 1281-307.

[3] W. X. Zhang, Y. Zhang, H. Zheng, C. Zhang, W. Xiong, J. G. Olyarchuk, M. Walker, W. F. Xu, M. Zhao, S. Q. Zhao, Z. Zhou and L. P. Wei, "A Synapse Protein DataBase Based on Synapse Ontology 2006,” Nucleic Acids Research, Vol. 35, No. S1, 2006, pp. D737-D741.

doi:10.1093/nar/gkl876

[4] S. J. Martin, P. D. Grimwood and R. G. M. Morris, "Synaptic Plasticity and Memory: An Evaluation of the Hypothesis," Annual Review of Neuroscience, Vol. 23, 2000, pp. 649-711. doi:10.1146/annurev.neuro.23.1.649

[5] J. Breustedt, A. Gundlfinger, F. Varoqueaux, K. Reim, N. Brose and D. Schmitz, "Munc13-2 Differentially Affects Hippocampal Synaptic Transmission and Plasticity,” Cerebral Cortex, Vol. 20, 2011, pp. 1109-1120.

[6] S. I. Cohen-Matsliah, H. Motanis, K. Rosenblum and E. Barkai, “A Novel Role for Protein Synthesis in Long-Term Neuronal Plasticity: Maintaining Reduced Postburst Afterhyperpolarization," The Journal of Neuroscience, Vol. 30, No. 12, 2010, pp. 4338-4342. doi:10.1523/JNEUROSCI.5005-09.2010

[7] A. B. Jerald, T. R. G. Nair and E. Rajasekaran, "Evaluation of the Structural Disorder of the Protein FMR1 with
Carbon Composition,” 2nd Annual Intrnational Conference on Advances in Biotechnology, 2012.

[8] D. C. Crawford, C. Y. Chang, K. L. Hyrc and S. Mennerick, "Calcium-Independant Inhibitory G-Protein Signaling Induces Persistent Presynaptic Muting of Hippocampal Synapses,” Journal of Neuroscience, Vol. 31, No. 3, 2011, pp. 979-991. doi:10.1523/JNEUROSCI.4960-10.2011

[9] K. L. Moulder, J. P. Meeks, A. A. Shute, C. K. Hamilton, G. de Erausquin and S. Mennerick, "Plastic Elimination of Functional Glutamate Release Sites by Depolarization,” Neuron, Vol. 42, No. 3, 2004, pp. 423-435. doi:10.1016/S0896-6273(04)00184-9

[10] K. L. Moulder, X. Jiang, C. Chang, A. A. Taylor, A. M. Benz, A. C. Conti, L. J. Muglia and S. Mennerick, “A Specific Role for Ca2-Dependant Adenylyl Cyclases in Recovery from Adaptive Presynaptic Silencing,” Journal of Neuroscience, Vol. 28, No. 20, 2008, pp. 5159-5168. doi:10.1523/JNEUROSCI.5317-07.2008

[11] R. C. Malenka and R. A. Nicoll, "Silent Synapses Speak Up,” Neuron, Vol. 19, No. 3, 1997, pp. 473-476. doi:10.1016/S0896-6273(00)80362-1

[12] L. L. Voronin and E. Cherubini, "Deaf, Mute and Whispering' Silent Synapses: Their Role in Synaptic Plasticity,” Journal of Physiology, Vol. 557, 2003, pp. 3-12. doi:10.1113/jphysiol.2003.058966

[13] D. Atasoy and E. T. Kavalali, "Presynaptic Unsilencing: Searching for a Mechanism,” Neuron, Vol. 50, No. 3, 2006, pp. 345-346. doi:10.1016/j.neuron.2006.04.018

[14] R. R. Linas, "The Contribution of Santiago Raman Y Cajal to the functional Neuroscience,” Nature, Vol. 4, 2003.

[15] M. Sheng and C. Sala, "PDZ Domains and the Organization of Supramolecular Complexes," Annuals of Review Neuroscience, Vol. 24, 2001, pp. 1-29. doi:10.1146/annurev.neuro.24.1.1

[16] H. J. Kreienkamp, "Organisation of G-Protein-Coupled Receptor Signalling Complexes by Scaffolding Proteins," Current Opinion in Pharmacology, Vol. 2, No. 5, 2002, pp. 581-586. doi:10.1016/S1471-4892(02)00203-5

[17] T. M. Boeckers, “The Postsynaptic Density," Cell Tissue Research, Vol. 326, No. 2, 2006, pp. 409-422. doi:10.1007/s00441-006-0274-5

[18] A. Haeckel, R. Ahuja, E. D. Gundelfinger, B. Qualmann and M. M. Kessels, "The Actin-Binding Protein Abp1 Controls Dendritic Spine Morphology and Is Important for Spine Head and Synapse Formation,” The Journal of Neuroscience, Vol. 28, No. 40, 2008, pp. 10031-10044.

[19] C. Dillon and Y. Goda, "The Actin Cytoskeleton: Integrating form and Function at Synapse," Annuals of Review Neuroscience, Vol. 28, 2005, pp. 25-55. doi:10.1146/annurev.neuro.28.061604.135757

[20] V. Schubert, J. S. Da Silva and C. G. Dotti, "Localized Recruitment and Activation of RhoA Underlies Dendritic Spine Morphology in a Glutamate Receptor-Dependant Manner,” Journal of Cell Biology, Vol. 172, No. 3, 2006, pp. 453-467. doi:10.1083/jcb.200506136

[21] Tada and M. Sheng, "Molecular Mechanisms of Dendritic Spine Morphogenesis," Current Opinion in Neurobiology, Vol. 16, No. 1, 2006, pp. 95-101. 
doi:10.1016/j.conb.2005.12.001

[22] G. Roussignol, F. Ango, S. Romorini, J. C. Tu, C. Sala, P. F. Worley, J. Bockaert and L. Fagni, "Shank Expression Is Sufficient to Induce Functional Dendritic Spine Synapses in Aspiny Neurons," Journal of Neuroscience, Vol. 25, No. 14, 2005, pp. 3560-3570. doi:10.1523/JNEUROSCI.4354-04.2005

[23] K. Shen and C. W. Cowan, "Guidance Molecules in Synapse Formation and Plasticity," Cold Spring Harbor Laboratory Press, 2010. doi:10.1101/cshperspect.a001842

[24] H. J. Kim and S. A. Thayer, "Lithium Increases Synapse Formation between Hippocampal Neurons by Depleting Phosphoinositides," Molecular Pharmacology, Vol. 75, No. 5, 2009, pp. 1021-1030. doi:10.1124/mol.108.052357

[25] P. G. Haydon, "GLIA: Listening and Talking to the Synapse," National Review of Neuroscience, Vol. 2, 2001, pp. 185-193. doi:10.1038/35058528

[26] R. D. Fields and B. Stevens-Graham, "New Insights into Neuron-Glia Communication,” Science, Vol. 298, No. 5593, 2002, pp. 556-562. doi:10.1126/science.298.5593.556

[27] D. S. Auld and R. Robitaille, "Perisynaptic Schwann Cells at the Neuromuscular Junction: Nerve- and Activity-Dependant Contributions to Synaptic Efficacy, Plasticity, and Reinnervation,” The Neuroscientist, Vol. 9, No. 2, 2003, pp. 144-157. doi:10.1177/1073858403252229

[28] G. I. Hatton and V. Parpura, "Glial Neuronal Signaling. Kluwer Academic, Boston, 2004. doi:10.1007/978-1-4020-7937-5

[29] N. J. Allen and B. A. Barres, "Signaling between Glia and Neurons: Focus on Synaptic Plasticity," Current Opinion in Neurobiology, Vol. 15, No. 5, 2005, pp. 542-548. doi:10.1016/j.conb.2005.08.006

[30] C.-P. Ko, Y. S. Sugiura and Z. Feng, "The Biology of Perisynaptic (Terminal) Schwann Cells,” In: P. J. Armati, Ed., The Biology of Schwann Cells: Development, Differentiation and Immunomodulation, 2007, pp. 72-99. doi:10.1017/CBO9780511541605.006

[31] Z. F. Kisvárday, et al., "Synaptic Targets of HRP-Filled Layer III Pyramidal Cells in the Cat Striate Cortex,” Experimental Brain Research, Vol. 64, No. 3, 1986, pp. 541-552. doi:10.1007/BF00340492

[32] A. Stepanyants and D. B. Chklovskii, "Neurogeometry and Potential Synaptic Connectivity," Trends Neuroscience, Vol. 28, No. 7, 2005, pp. 387-394. doi:10.1016/j.tins.2005.05.006

[33] A. Stepanyants, P. R. Hof and D. B. Chklovskii, "Geometry and Structural Plasticity of Synaptic Connectivity,” Neuron, Vol. 34, No. 2, 2002, pp. 275-288. doi:10.1016/S0896-6273(02)00652-9

[34] Tarec Fares and Armen Stepanyants, "Cooperative Synapse Formation in the Neocortex,” PNAS, Vol. 106, No. 38, 2002, pp. 16463-16468. www.pnas.org cgi doi 10.1073 pnas.0813265106.

[35] N. Kalisman, G. Silberberg and H. Markram, “The Neocortical Microcircuit as a Tabularasa," Proceedings of National Academy of Science of the USA, Vol. 102, No. 3, 2005, pp. 880-885. doi:10.1073/pnas.0407088102
[36] D. Feldmeyer, V. Egger, J. Lubke and B. Sakmann, “Reliable Synaptic Connections between Pairs of Excitatory Layer 4 Neurones within a Single 'Barrel' of Developing Rat Somatosensory Cortex,” The Journal of Physiology, Vol. 521, No. 1, 1999, pp. 169-190. doi:10.1111/j.1469-7793.1999.00169.x

[37] D. Feldmeyer, J. Lubke, R. A. Silver and B. Sakmann, "Synaptic Connections between Layer 4 Spiny Neurone-Layer 2/3 Pyramidal Cell Pairs in Juvenile Rat Barrel Cortex: Physiology and Anatomy of Interlaminar Signalling within a Cortical Column," The Journal of Physiology, Vol. 538, No. 3, 2002, pp. 803-822. doi:10.1113/jphysiol.2001.012959

[38] H. Markram, J. Lubke, M. Frotscher, A. Roth and B. Sakmann, "Physiology and Anatomy of Synaptic Connections between Thick Tufted Pyramidal Neurones in the Developing Rat Neocortex," The Journal of Physiol$o g y$, Vol. 500, No. 2, 1997, pp. 409-440.

[39] U. V. Nagerl, G. Kostinger, J. C. Anderson, K. A. Martin and T. Bonhoeffer, "Protracted Synaptogenesis after Activity-Dependant Spinogenesis in Hippocampal Neurons," The Journal of Neuroscience, Vol. 27, No. 30, 2007, pp. 8149-8156. doi:10.1523/JNEUROSCI.0511-07.2007

[40] K. Matsumoto-Miyai, et al., "Coincident Pre- and Postsynaptic Activation Induces Dendritic Filopodia via Neurotrypsin-Dependant Agrin Cleavage," Cell, Vol. 136, No. 6, 2009, pp. 1161-1171. doi:10.1016/j.cell.2009.02.034

[41] T. Branco and K. Staras, "The Probability of Neurotransmitter Release: Variability and Feedback Control at Single Synapses," Nature Reviews of Neuroscience, Vol. 10, No. 5, 2009, pp. 373-383. http://www.ncbi.nlm.nih.gov/pubmed/19377502/

[42] I. Riebe and E. Hanse, "Development of Synaptic Connectivity onto Interneurons in Stratum Radiatum in the CA1 Region of the Rat Hippocampus," BMC Neuroscience, Vol. 13, No. 1, 2012, p. 14. doi:10.1186/1471-2202-13-14

[43] E. De Robertis, "Submicroscopic Morphology of the Synapse,” International Review of Cytology, Vol. 8, 1959, pp. 61-96. doi:10.1016/S0074-7696(08)62728-X

[44] R. W. Guillery, "Early Electron Microscopic Observations of Synaptic Structures in the Cerebral Cortex: A View of the Contributions Made by George Gray (19241999)," Trends in Neuroscience, Vol. 23, No. 12, 2000, pp. 594-598. doi:10.1016/S0166-2236(00)01635-0

[45] J. Gerlach, “The Spinal Cord,” In: S. Stricker, Ed., Manual of Histology, Williams and Wood \& Co., New York, 1872, pp. 327-366.

[46] E. Deiters and R. W. Guillery, “Otto Deiters: 1834-1863," Experimental Neurology, Vol. 9, No. 1, 1963, pp. iii-vi.

[47] E. G. Gary and R. W. Guillery, "Synaptic Morphology in the Normal and Degenerating Nervous System,” International Review of Cytology, Vol. 19, 1996, pp. 111-182. doi:10.1016/S0074-7696(08)60566-5

[48] C. Golgi, "La Doctrine du Neurone, Theorie et Faits," In: K. B. Hasselberg, S. O. Pettersson, K. A. H. Morner, C. D. Wirsen and M. C. G. Santesson, Eds., Les prix Nobel: 1906, Imprimerie Royale, Norstedt \& Soner, Stockholm, 
1908, pp. 1-31.

[49] F. Nissl, D. Neuronenlehre and I. Anhänger, "Ein Beitrag zur Lo“"sung des Problems der Beziehungen zwischen Nervenzelle,” Faser und Grau, Gustav Fisher, Jena, 1903.

[50] L. Shapiro and D. R. Coleman, “The Diversity of Cadherins and the Implications for a Synaptic Adhesive Code in the CNS," Neuron, Vol. 23, No. 3, 1999, pp. 427-430. doi:10.1016/S0896-6273(00)80796-5

[51] S.-K. Kwon, J. Woo, S.-Y. Kim, H. Kim and E. Kim, "Trans-Synaptic Adhesions between Netrin-G Ligand-3 (NGL-3) and Receptor Tyrosine Phosphatases LAR, Protein-Tyrosine Phosphatase_(PTP_), and PTP_ via Specific Domains Regulate Excitatory Synapse Formation,” The Journal of Biological chemistry, Vol. 285, No. 18, 2010, pp. 13966-13978.

[52] M. V. Bennett and R. S. Zukin, "Electrical Coupling and Neuronal Synchronization in the Mammalian Brain," Neuron, Vol. 41, No. 4, 2004, pp. 495-511. doi:10.1016/S0896-6273(04)00043-1

[53] B. W. Connors and M. A. Long, "Electrical Synapses in the Mammalian Brain,” Annual Review of Neuroscience, Vol. 27, No. 1, 2004, pp. 393-418. doi:10.1146/annurev.neuro.26.041002.131128

[54] S. Hestrin and M. Galarreta, "Electrical Synapses Define Networks of Neocortical GABAergic Neurons," Trends in Neuroscience, Vol. 28, No. 6, 2005, pp. 304-309. doi:10.1016/j.tins.2005.04.001

[55] R. Bruzzone and R. Dermietzel, "Structure and Function of Gap Junctions in the Developing Brain," Cell and Tissue Research, Vol. 326, No. 2, 2006, pp. 239-248. doi:10.1007/s00441-006-0287-0

[56] B. Sutor and T. Hagerty, "Involvement of Gap Junctions in the Development of the Neocortex," Biochimia et Biophys Acta, Vol. 1719, No. 1-2, 2005, pp. 59-68. doi:10.1016/j.bbamem.2005.09.005

[57] P. Washbourne, J. E. Bennet and A. K. McAllister, "Rapid Recruitment of NMDA Receptor Transport Packets to Nascent Synapses,” Nature Neuroscience, Vol. 5, No. 8, 2002, pp. 751-759.

[58] R. C. Malenka and R. A. Nicoll, "NMDA-Receptor-Dependant Synaptic Plasticity: Multiple Forms and Mechanisms," Trends in Neuroscience, Vol. 16, No. 12, 1993, pp. 521-527. doi:10.1016/0166-2236(93)90197-T

[59] K. Fox, B. L. Schlaggar, S. Glazewski and D. D. O’Leary, “Glutamate Receptor Blockade at Cortical Synapses Disrupts Development of Thalamocortical and Columnar Organization in Somatosensory Cortex," Proceedings of National Academy of Science of USA, Vol. 93, No. 11, 1996, pp. 5584-5589. doi:10.1073/pnas.93.11.5584

[60] L. Huang and S. L. Pallas, "NMDA Antagonists in the Superior Colliculus Prevent Developmental Plasticity but Not Visual Transmission or Map Compression,” Journal of Neurophysiology, Vol. 86, No. 3, 2001, pp. 1179-1194.

[61] D. Liao, N. A. Hessler and R. Malinow, "Activation of Postsynaptically Silent Synapses during Pairing-Induced LTP in CA1 Region of Hippocampal Slice," Nature, Vol. 375, No. 6530, 1995, pp. 400-404. doi:10.1038/375400a0

[62] R. Malinow, Z. F. Mainen and Y. Hayashi, "LTP Mecha- nisms: From Silence to Four-Lane Traffic," Current Opinion in Neurobiology, Vol. 10, No. 3, 2000, pp. 352-357. doi:10.1016/S0959-4388(00)00099-4

[63] M. Y. Xiao, H. Wigstrom and B. Gustafsson, "LongTerm Depression in the Hippocampal CA1 Region Is Associated with Equal Changes in AMPA and NMDA Receptor-Mediated Synaptic Potentials,” European Journal of Neuroscience, Vol. 6, No. 6, 1994, pp. 1055-1057. doi:10.1111/j.1460-9568.1994.tb00600.x

[64] R. C. Carroll, D. V. Lissin, M. V. Zastrow, R. A. Nicoll and R. C. Malenka, "Rapid Redistribution of Glutamate Receptors Contributes to Long-Term Depression in Hippocampal Cultures,” Nature Neuroscience, Vol. 2, No. 5, 1999, pp. 454-460. doi:10.1038/8123

[65] V. A. Alvarez, A. D. Ridenour and L. B. Sabatini, "Distinct Structural and Ionotropic Roles of NMDA Receptors in Controlling Spine and Synapse Stability,” The Journal of Neuroscience, Vol. 27, No. 28, 2007, pp. 7365-7376. doi:10.1523/JNEUROSCI.0956-07.2007

[66] J. R. Sanes and J. W. Lichtman, "Induction, Assembly, Maturation and Maintenance of a Postsynaptic Apparatus,” Nature Reviews Neuroscience, Vol. 2, No. 11, 2001, pp. 791-805. doi:10.1038/35097557

[67] I. I. Moraru and L. M. Loew, "Intracellular Signaling: Spatial and Temporal Control,” Pysiology, Vol. 20, No. 3, 2005, pp. 169-179, doi:10.1152/physiol.00052.2004

[68] N. C. Danbolt, “Glutamate Uptake,” Progress in Neurobiology, Vol. 65, No. 1, 2001, pp. 1-105. doi:10.1016/S0301-0082(00)00067-8

[69] S. H. Oliet, R. Piet, D. A. Poulain and D. T. Theodosis, "Glial Modulation of Synaptic Transmission: Insights from the Supraoptic Nucleus of the Hypothalamus," Glia, Vol. 47, No. 3, 2004, pp. 258-267. doi:10.1002/glia.20032

[70] D. A. Henze, L. Wittner and G. Buzsáki, “Single Granule Cells Reliably Discharge Targets in the Hippocampal CA3 Network in Vivo," Nature Neuroscience, Vol. 5, No. 8, 2002, pp. 790-795.

[71] J. J. Lawrence, Z. M. Grinspan and C. J. McBain, “Quantal Transmission at Mossy Fibre Targets in the CA3 Region of the Rat Hippocampus," The Journal of Physiology, Vol. 554, No. 1, 2003, pp. 175-193. doi:10.1113/jphysiol.2003.049551

[72] J. Bischofberger, D. Engel, M. Frotscher and P. Jonas, "Timing and Efficacy of Transmitter Release at Mossy Fiber Synapses in the Hippocampal Network,” Pflügers Archiv, Vol. 453, No. 2, 2006, pp. 361-372. doi:10.1007/s00424-006-0093-2

[73] H. L. Atwood and S. Karunanithi, "Diversification of Synaptic Strength: Presynaptic Elements," Nature Reviews Neuroscience, Vol. 3, No. 7, 2002, pp. 497-516.

[74] H. W. Tao and M.-M. Poo, "Retrograde Signaling at Central Synapses," Proceedings of National Academy of Science of USA, Vol. 98, No. 20, 2001, pp. 11009-11015. doi:10.1073/pnas.191351698

[75] W.-X. Zhang, et al., "SynDB: A Synapse Protein DataBase Based on Synapse Ontology," Nucleic Acids Research, Vol. 35, Sup. 1, 2007, pp. D737-D741 


\section{doi:10.1093/nar/gkl876}

[76] K. Nakazawa, T. J. McHugh, M. A. Wilson and S. Tonegawa, "NMDA Receptors, Place Cells and Hippocampal Spatial Memory,” Nature Reviews Neuroscience, Vol. 5, No. 5, 2004, pp. 361-372.

[77] J. K. Leutgeb, S. Leutgeb, M. B. Moser and E. I. Moser, "Pattern Separation in the Dentate Gyrus and CA3 of the Hippocampus,” Science, Vol. 315, No. 5814, 2007, pp. 961-966. doi:10.1126/science.1135801

[78] T. Nakashiba, J. Z. Young, T. J. McHugh, D. L. Buhl and S. Tonegawa, "Transgenic Inhibition of Synaptic Transmission Reveals Role of CA3 Output in Hippocampal Learning,” Science, Vol. 319, No. 5867, 2008, pp. 12601264. doi:10.1126/science. 1151120

[79] B. Bingol and E. M. Schuman, "A Proteasome-Sensitive Connection between PSD-95 and GluR1 Endocytosis," Neuropharmacology, Vol. 47, No. 5, 2004, pp. 755-763. doi:10.1016/j.neuropharm.2004.07.028

[80] J. J. Yi and M. D. Ehlers, "Emerging Roles for Ubiquitin and Protein Degradation in Neuronal Function," Pharmacological Reviews, Vol. 59, No. 1, 2007, pp. 14-39. doi:10.1124/pr.59.1.4

[81] K. F. Haas and K. Broadie, "Roles of Ubiquitination at the Synapse,” Biochimica et Biophysica Acta, Vol. 1779, No. 8, 2008, pp. 495-506. doi:10.1016/j.bbagrm.2007.12.010

[82] P. Kaiser and E. A. Fon, "Expanding Horizons at Big Sky. Symposium on Ubiquitin and Signaling," EMBO Reports, Vol. 8, No. 9, 2007, pp. 817-822. doi:10.1038/sj.embor.7401017

[83] G. V. Rinettil and F. E. Schweizer, "Ubiquitination Acutely Regulates Presynaptic Neurotransmitter Release in Mammalian Neurons," The Journal of Neuroscience, Vol. 30, No. 9, 2010, pp. 3157-3166.

[84] T. Sun, X.-S. Wu, J.-H. Xu, B. D. McNeil, Z. P. Pang, W.-J. Yang, L. Bai, S. Qadri, J. D. Molkentin, D. T. Yue and L.-G. Wu, "The Role of Calcium/Calmodulin-Activated Calcineurin in Rapid and Slow Endocytosis at Central Synapses,” The Journal of Neuroscience, Vol. 30, No. 35, 2010, pp. 11838-11847. doi:10.1523/JNEUROSCI.1481-10.2010

[85] C. E. Flores, R. Cachope, S. Nannapaneni, S. Ene, A. C. Nairn and A. E. Peredal, "Variability of Distribution of $\mathrm{Ca}^{+} /$Calmodulin-Dependant Kinase II at Mixed Synapses on the Mauthner Cell: Colocalization and Association with Connexin 35," The Journal of Neuroscience, Vol. 30, No. 28, 2010, pp. 9488-9499.

[86] M. M. Rosenberg, F. Yang, J. L. Mohn, E. K. Storer and M. H. Jacob, "The Postsynaptic Adenomatous Polyposis Coli (APC) Multiprotein Complex Is Required for Localizing Neuroligin and Neurexin to Neuronal Nicotinic Synapses in Vivo," The Journal of Neuroscience, Vol. 30, No. 33, 2010, pp. 11073-11085.

[87] K. C. Marsdena, A. Shemesha, K. U. Bayerb and R. C. Carrolla, "Selective Translocation of $\mathrm{Ca}^{+} /$Calmodulin Protein Kinase II $\alpha$ (CaMKII $\alpha)$ to Inhibitory Synapses," Proceedings of National Academy of Science of USA, Vol. 107, No. 47, 2010, pp. 20559-20564.
[88] S. K. Tyagarajana, H. Ghosha, G. E. Yévenesa, I. Nikonenkob, C. Ebelinga, C. Schwerdela, C. Sidlera, H. U. Zeilhofera, B. Gerritsc, D. Mullerb and J.-M. Fritschya, "Regulation of GABAergic Synapse Formation and Plasticity by GSK3 $\beta$-Dependant Phosphorylation of Gephyrin,” Vol. 108, No. 1, 2011, pp. 379-384.

[89] C. R. Sunico, D. Gonzalez-Forero, G. Domínguez, J. M. García-Verdugo and B. Moreno-Lopezl, "Nitric Oxide Induces Pathological Synapse Loss by a Protein Kinase G-, Rho Kinase-Dependant Mechanism Preceded by Myosin Light Chain Phosphorylation," The Journal of Neuroscience, Vol. 30, No. 3, 2010, pp. 973-984.

[90] J.-Y. Hu, Y. Chen and S. Schacher, "Multifunctional Role of Protein Kinase C in Regulating the Formation and Maturation of Specific Synapses," The Journal of Neuroscience, Vol. 27, No. 43, 2007, pp. 11712-11724

[91] T. J. Siddiqui, R. Pancaroglu, Y. Kang, A. Rooyakkers and A. M. Craig, "LRRTMs and Neuroligins Bind Neurexins with a Differential Code to Cooperate in Glutamate Synapse Development," The Journal of Neuroscience, Vol. 30, No. 22, 2010, pp. 7495-7506

[92] E. J. Huang and L. F. Reichardt, "Trk Receptors: Roles in Neuronal Signal Transduction," Annual Reviews of Biochemistry, Vol. 72, 2003, pp. 609-642. doi:10.1146/annurev.biochem.72.121801.161629

[93] B. W. Luikart and L. F. Parada, "Receptor Tyrosine Kinase Bmediated Excitatory Synaptogenesis,” Progress in Brain Research, Vol. 157, 2006, pp. 15-24. doi:10.1016/S0079-6123(06)57002-5

[94] Y. Lu, K. Christian and B. Lu, "BDNF: A Key Regulator for Protein Synthesis-Dependant LTP and Long-Term Memory?" Neurobiology of Learning and Memory, Vol. 89, No. 3, 2008, pp. 312-323. doi:10.1016/j.nlm.2007.08.018

[95] J. Schulte, K. J. Sepp, R. A. Jorquera, C. Wu, Yun Song, P.-Y. Hong and J. T. Littleton, "DMob4/Phocein Regulates Synapse Formation, Axonal Transport, and Microtubule Organization," The Journal of Neuroscience, Vol. 30, No. 15, 2010, pp. 5189-5203.

[96] W. Mah, J. Ko, J. Nam, K. Han, W. S. Chung and E. Kim, "Selected SALM (Synaptic Adhesion-Like Molecule) Family Proteins Regulate Synapse Formation,” The Journal of Neuroscience, Vol. 30, No. 16, 2010, pp. 55595568.

[97] C. N. G. Giachello, F. Fiumara, C. Giacomini, A. Corradi, C. Milanese, M. Ghirardi, F. Benfenati and P. G. Montarolo, "MAPK/Erk-Dependant Phosphorylation of Synapsin Mediates Formation of Functional Synapses and Short-Term Homosynaptic Plasticity," Journal of Cell Science, Vol. 123, 2010, pp. 881-893. doi:10.1242/jcs.056846

[98] P. T. Hallock, C.-F. Xu, T.-J. Park, T. A. Neubert, T. Curran and S. J. Burden, "Dok-7 Regulates Neuromuscular Synapse Formation by Recruiting Crk and Crk-L," Genes Development, Vol. 24, No. 21, 2010, pp. 24512461. doi:10.1101/gad.1977710

[99] P. García-Junco-Clemente, G. Cantero, L. Gomez-Sanchez, P. Linares-Clemente, J. A. Martínez-Lopez, R. Lujan and R. Fernandez-Chacon, "Cysteine String Protein- $\alpha$ 
Prevents Activity-Dependent Degeneration in GABAergic Synapses,” The Journal of Neuroscience, Vol. 30, No. 21, 2010, pp. 7377-7391.

[100] M. Zhao, J. Raingo, Z.-J. “James” Chen and E. T. Kavalali, "Cc2d1a, a C2 Domain Containing Protein Linked to Nonsyndromic Mental Retardation, Controls Functional Maturation of Central Synapses," Journal of Neurophysiology, Vol. 105, No. 4, 2011, pp. 1506-1515. doi:10.1152/jn.00950.2010

[101] P.-Y. Deng, Z.-Y. Xiao, A. Jha, D. Ramonet, T. Matsui, M. Leitges, H.-S. Shin, J. E. Porter, J. D. Geiger and S. Lei, "Cholecystokinin Facilitates Glutamate Release by Increasing the Number of Readily Releasable Vesicles and Releasing Probability,” The Journal of Neuroscience, Vol. 30, No. 15, 2010, pp. 5136-5148.

[102] C. G. Evans, B. C. Ludwar, T. Kang and E. C. Cropper, "Effect of Presynaptic Membrane Potential on Electrical vs. Chemical Synaptic Transmission,” Journal of Neurophysiology, Vol. 106, No. 2, 2011, pp. 680-689.

[103] K. L. Todd, W. B. Kristan Jr. and A. Kathleen "French Gap Junction Expression Is Required for Normal Chemical Synapse Formation," The Journal of Neuroscience, Vol. 30, No. 45, 2010, pp. 15277-15285.

[104] C. G. Evans, B. C. Ludwar, T. Kang and E. C. Cropper, "Effect of Presynaptic Membrane Potential on Electrical vs. Chemical Synaptic Transmission," Journal of Neurophysiology, Vol. 106, No. 2, 2011, pp. 680-689. doi:10.1152/jn.00340.2011

[105] D. M. Kullmann and K. P. Lamsa, "Long-Term Synaptic Plasticity in Hippocampal Interneurons,” Nature Reviews Neuroscience, Vol. 8, No. 9, 2007, pp. 687-699.

[106] R. Scott, T. Lalic, D. M. Kullmann, M. Capogna and D. A. Rusakov, "Target-Cell Specificity of Kainate Autoreceptor and $\mathrm{Ca}_{2}{ }^{+}$-store-Dependent Short-Term Plasticity at Hippocampal Mossy Fiber Synapses," The Journal of Neuroscience, Vol. 28, No. 49, 2008, pp. 13139-13149. doi:10.1523/JNEUROSCI.2932-08.2008

[107] K. A. Pelkey, L. Topolnik, J. C. Lacaille and C. J. McBain, "Compartmentalized $\mathrm{Ca}^{2+}$ Channel Regulation at Divergent Mossy-Fiber Release Sites Underlies Target Cell-Dependent Plasticity,” Neuron, Vol. 52, No. 3, 2006. pp. 497-510. doi:10.1016/j.neuron.2006.08.032

[108] U. Pannascha, L. Vargová, J. Reingruberd, P. Ezana, D.
Holcmand, C. Giaumea, E. Syková and N. Rouacha, “Astroglial Networks Scale Synaptic Activity and Plasticity,” Proceedings of National Academy of Science of USA, Vol. 108, No. 20, 2011, pp. 8467-8472.

www.pnas.org/cgi/doi/10.1073/pnas.1016650108

[109] F. Canal, O. Palygin, Y. Pankratov, S. A. L. Correa and J. Muller, "Compartmentalization of the MAPK Scaffold Protein KSR1 Modulates Synaptic Plasticity in Hippocampal Neurons," The FASEB Journal Research Communication, Vol. 25, No. 7, 2011, pp. 2362-2372. doi:10.1096/fj.10-173153

[110] R. Cachope, "Functional Diversity on Synaptic Plasticity Mediated by Endocannabinoids,” Philosophical Transactions of the Royal Society B, Vol. 367, No. 1607, 2012, pp. 3242-3253. doi:10.1098/rstb.2011.0386

[111] D. S. Shin, W. Yu, A. Fawcett and P. L. Carlen, “Characterizing the Persistent CA3 Interneuronal Spiking Activity in Elevated Extracellular Potassium in the Young Rat Hippocampus,” Brain Research, Vol. 1331, 2010, pp. 3950. doi:10.1016/j.brainres.2010.03.023

[112] D. S. Shin, W. Yu, A. Sutton, M. Calos and P. L. Carlen, "Elevated Potassium Elicits Recurrent Surges of Large GABAA-Receptor Mediated Post-Synaptic Currents in Hippocampal CA3 Pyramidal Neurons,” Journal of Neurophysiology, Vol. 105, No. 3, 2011, pp. 1185-1198. doi:10.1152/jn.00770.2010

[113] S. Olah, M. Fule, G. Komlosi, et al., "Regulation of Cortical Microcircuits by Unitary GABA-Mediated Volume Transmission," Nature, Vol. 461, No. 7268, 2009, pp. 1278-1281. doi:10.1038/nature08503

[114] T. Kimata, et al., "Synaptic Polarity Depends on Phosphatidylinositol Signaling Regulated by Myo-Inositol Monophosphatase in Caenorhabditis Elegans," Genetics, Vol. 191, No. 2, 2012, pp. 509-521.

[115] L. A. Jarzylo and H.-Y. Man, "Parasynaptic NMDA Receptor Signaling Couples Neuronal Glutamate Transporter Function to AMPA Receptor Synaptic Distribution and Stability,” The Journal of Neuroscience, Vol. 32, No. 7, 2012, pp. 2552-2563. doi:10.1523/JNEUROSCI.3237-11.2012

[116] R. W. Guillery, "Histology of the Nervous System (Book Review),” Trends in Neuroscience, Vol. 19, No. 4, 1996, pp. 156-157. doi:10.1016/S0166-2236(96)80029-4 